\title{
CHERT IN THE BARTON PEBBLE BED.
}

Sir,-In 1912 Messrs. Bromehead and Dewey announced their important discovery of the occurrence of Lower Greensand Chert in the Barton Pebble Bed of the London Basin. Its bearing on the date of the uncovering of the Weald is evident and has frequently been commented on, whilst this supposed source of chert has also been laid under contribution to explain the occurrence of chert in the hill gravels of North London, where, however, the chert is vastly more abundant and in much larger fragments than in the Barton Pebble Bed. The record, however, is based, as far as I can learn, on a single locality-Stanners Hill, near Woking--where the overlying Barton Sands are not present above the pebble-bed, which here forms the hill-top. This leaves an uncomfortable doubt as to the possibility of a later introduction of the chert, since it is common in the Plateau Gravels of the area. I think it may prove possible to distinguish the chert pebbles in the Stanners Hill shingle from those of the Plateau Gravels, but it is clearly desirable that new records should be made from places where the Barton Sand is in situ above. I should, therefore, be grateful if any of your readers could direct my attention either to existing exposures which show the pebble-bed or to places where excavation might be advantageously undertaken. I have written this letter in the hope also that it will lead to a careful scrutiny of any temporary excavations which may be visible from time to time.

J. F. KirkaLdy.

King's College, LONDON. 4 th April, 1932.

\section{The late Professor J. W. Gregory, F.R.S.}

For some time past, for good reasons, the practice of publishing obituary notices in the Geological Magazine has been discontinued. It seems impossible, however, to pass over in silence the tragic death of Prof. J. W. Gregory, who, as announced in The Times, was drowned in northern Peru in the middle of last month. For many years Professor Gregory has been one of the Editorial Advisers of this Magazine: he often gave wise counsel, as well as unswerving support at a critical time, some twelve years ago, when the very existence of the Magazine hung in the balance. His work as geologist and explorer is too well known to need detailed mention here, and the Editor can only express his deep personal regret at the loss of so valued a colleague. 